\title{
ANALISIS KEBUTUHAN MAHASISWA TERHADAP BAHAN AJAR SEBAGAI ACUAN PENGEMBANGAN MODUL FISIKA GELOMBANG BOLA DAN TABUNG
}

Wawan Kurniawan ${ }^{1}$, Febri Berthalita Pujaningsih ${ }^{2}$, Alrizal $^{3}$, Nindi Ayu Latifah ${ }^{4}$

1,2,3,4Program Studi Pendidikan Fisika, Universitas Jambi, Jambi, Indonesia

kurniawan_wawan@unja.ac.id ${ }^{1}$, febri.bethalita@unja.ac.id ${ }^{2}$, alrizal@unja.ac.id ${ }^{3}$, nindiayu397@gmail.com ${ }^{4}$

\section{Info Artikel}

\section{Alamat Korespondensi:}

Email: kurniawan_wawan@unja.ac.id

\begin{abstract}
Abstrak:
Penelitian ini bertujuan untuk menganalisis kebutuhan mahasiswa tehogdap bahan ajar yang diperlukan pada matakuliah Gelombang dan Optik. Penelitian ini merupakan penelitian deskiptif eksploratif dengan subjek penelitian mahasiswa perodidikan fisika angkatan 2015 Universitas Jambi yang tellh mengontrak matakuliah Gelombang dan Optik. Sampel \&ang digunakan untuk penelitian ini diambil secara acak dengan total sampel sebanyak 25 mahasiswa. Data penelitian diperoleh dari pengisian lembar observasi awal dan angket kebutuhan terhadap bahan ajar yang diinginkan. Hasjl observasi awal menunjukan bahwa bahan ajar pada perkụliahan Gelombang dan Optik masih belum dapat menjelaskan konten pembelajaran secara rinci, baik dari segi materi maupun visualisasi. Hasil analisis angket kebutuhan terhddap pengembangan bahan ajar menunjukkan bahwa mahasisava membutuhkan bahan ajar yang mampu menjelaskan materi pembelajaran secara rinci, dilengkapi dengan penurunan rumus dan visualisai konten pembelajaran yang bersifat abstrak.
\end{abstract}

Kata kunci: Analisis kebutuhan, bahan ajar (C) C 2018 Pendidikan Fisika Universitas Jambi 


\section{Pendahuluan}

Proses perkuliahan erat kaitannya dengan media pembelajaran. Salah satu media pembelajaran yang efektif dan paling familiar untuk digunakan adalah bahan ajar. Penggunaan bahan ajar yang berkalitas dapat membantu pengajar untuk menyampaikan materi pembelajaran secara maksimal. Bahan ajar sebaiknya disusun dengan mengikuti suatu aturan tertentu yang sitematis, artinya bahan ajar yang baik hendaknya memiliki sintak penyusunan yang disesuaikan dengan tujuan dari dibentuknya bahan ajar tersebut. Selain itu, bahan ajar yang dirancang dengan baik dan terstruktur juga dapat mempengaruhi tingkat keberhasilan proses pembelajaran.

Menurut Kristanto (2011) bahan ajar atau materi pembelajaran (instructional materials) secara garis besar terdiri atas pengetahuan keterampilan dan sikap yang harus dipelajari mahasiswa dalam rangka mencapai standar kompetensi yang telah ditentukan. Beberapa bentuk bahan ajar diantaranya yaitu: Bahan cetak, seperti: buku, modul cetak, lembar kerja siswa, brosur, leaflet dan wallchart. Audio, seperti: video film dan VCD. Multimedia, seperti: CD interaktif dan internet.

Bahan ajar yang menarik sangat dibutuhkan dalam proses pembelajaran karena dapat meningkatkan motivasi dan minat belajar mahasiswa. Bahan ajar digunakan oleh pendidik untuk mengajar di berbagai bidang ilmu, salah satunya yaitu ilmu fisika. Fisika merupakan suatu ilmu yang membahas berbagai fenomena alam dan mengetahui keterkaitannya dengan ilmu yang ada. Agar ilmu fisika dapat tersampaikan dengan baik kepada mahasiswa, maka pendidik membutuhkan bahan ajar yang efektif untuk digunakan. Bahan ajar yang berkualitas adalah salah satu contoh bahan ajar yang efektif untuk digunakan.

Kajian materi ilmu fisika dalam konteks perkuliahan memiliki cakupan yang cukup luas dan mendalam, salah satunya yaitu mata kuliah Gelombang dan Optik. Gelombang dan Optik merupakan salah satu matakuliah wajib bagi mahasiswa jenjang pendidikan S1 prodi Pendidikan Fisika di Universitas Jambi. Pokok kajian materi perkuliahan yang harus dipahami pada mata kuliah ini yaitu megenai fenomena gelombang dan peristiwa-perisiwa optik. Pembelajaran pada matakuliah Gelombang dan Optik membutuhkan bahan ajar yang mampu menunjang perkuliahan. Namun kenyataan menyatakan bahwa bahan ajar yang selama ini digunakan masih memiliki kelemahankelemahan yang perlu diperbaiki. Kelemahan tersebut berasal dari bahan ajar masih belum memaparkan penjelasan konten pembelajaran secara rinci, baik dari segi materi maupun visualisasi. Selain itu, bahan ajar dirasa cukup sulit dipahami karena menggunakan pengantar berbahasa asing. Oleh karena itu, perlu dilakukan upaya perbaikan bahan ajar pada matakuliah tersebut. Salah satu upaya yang dapat dilakukan yaitu dengan melakukan pengembangan bahan ajar baru yang dapat mempermudah penalaran konsep mahasiswa dan mampu menyelesaikan permasalahan yang ada, sehingga mahasiswa dapat memahami konsep pembelajaran secara mandiri.

Tujuan dari penelitian ini adalah untuk mengetahui jenis bahan ajar yang perlu dikembangkan pada sub topik pembelajaran Gelombang matakuliah Gelombang dan Optik di Universitas Jambi melalui lembar observasi awal dan angket kebutuhan.. Hasil penelitian ini diharapkan dapat memberikan informasi mengenai jenis bahan ajar yang perlu dikembangkan untuk meningkatkan pemahaman dan minat mahasiswa dalam mempelajari materi fisika gelombang matakuliah Gelombang dan Optik baik secara mandiri maupun pembelajaran di kelas.

\section{Metode Penelitian}

Jenis Penelitian

Penelitian ini merupakan jenis penelitian deskriptif eksploratif.

\section{Waktu dan Tempat Penelitian}

Penelitian ini dilakukan pada bulan Juli-Agustus 2018 pada Program Studi Pendidikan Fisika Fakultas Keguruan dan Ilmu Pendidikan Universitas Jambi.

Subjek Penelitian

Subjek penelitian ini adalah mahasiswa pendidikan fisika angkatan 2015 Universitas Jambi yang telah mengontrak matakuliah Gelombang dan Optik. Sampel yang digunakan untuk penelitian ini diambil secara acak dengan total sampel sebanyak 25 mahasiswa. 
Prosedur

Data penelitian diperoleh dari pengisian lembar observasi awal dan angket kebutuhan terhadap bahan ajar yang diinginkan oleh subjek penelitian. Observasi awal merupakan suatu kegiatan yang dilakukan peneliti untuk mengetahui kendala-kendala yang dirasakan oleh subjek penelitian terhadap kelengkapan bahan ajar yang digunakan pada matakuliah Gelombang dan Optik. Sedangkan angket kebutuhan merupakan suatu instrumen yang peneliti gunakan untuk mengentahui upaya tindak lanjut penanganan masalah yang diharapkan oleh subjek penelitian mengenai bahan ajar yang digunakan dalam perkuliahan, supaya peneliti dapat memberikan solusi yang tepat dan sesuai dengan keinginan subjek penelitian.

Teknik Analisis Data

Instumen penelitian berupa lembar observsai awal terhadap kebutuhan bahan ajar dan angket kebutuhan akan menghasilkan suatu data penelitian. Data yang diperoleh berupa data kualitatif dan kuantitatif. Data-data tersebut akan dianalisis secara deskriptif dengan cara menyusun data secara sitematis, mengorganisasi data ke dalam kategori yang ada, melakukan sintesa, menyusun dalam pola tertentu, dan membuat kesimpulan secara naratif.

\section{Hasil Penelitian dan Pembahasan}

Penelitian terhadap analisis kebutuhan mahasiswa akan bahan ajar yang dapat menunjang perkuliahan Gelombang dan Optik dilakukan dengan menggunakan instrumen pengumpul data berbentuk lembar observasi dan angket kebutuhan. Dua instrumen tersebut dibagikan kepada 25 mahasiswa sebagai sampel acak dari subjek penelitian.Instrumen yang lebih dahulu dibagikan kepada subjek penelitian yaitu lembar observasi awal untuk menganalisis kebutuhan mahasiswa, setelah itu dilanjutkan dengan pengisian angket kebutuhan mahasiswa terhadap bahan ajar pada matakuliah Gelombang dan Optik. Susunan data hasil observasi awal dan angket kebutuhan mahasiswa dapat dilihat pada tabel 1 dan 2 .

Berdasarkan hasil pengamatan selama proses perkuliahan Gelombang dan Optik, mayoritas mahasiswa berasumsi bahwa matakuliah tersebut adalah matakuliah yang sulit dipahami. Mayoritas mahasiswa memberikan respon belajar yang kurang antusias dikarenakan beberapa faktor kendala yang mempengaruhi. Beberapa kendala yang dirasakan oleh mahasiswa adalah kurangnya pengetahuan dasar materi pembelajaran, penyajian materi pada bahan ajar yang sulit untuk di pahami, kurangnya partisipasi mahasiswa di kelas, dan bahan ajar berupa buku teks dengan pengantar bahasa asing. Kesulitan dan kendala yang dirasakan oleh mahasiswa berdampak terhadap proses pembelajaran, karena mahasiswa sudah berpikir bahwa materi pembelajaran tersebut sulit sehingga mahasiswa cenderung diam dan kurang aktif. Untuk mengatasi permasalahan tersebut dosen pengampu matakuliah telah melakukan perubahan terhadap model pembelajaran dari ceramah menjadi presentasi dan diskusi kelompok, sehingga mahasiswa dapat lebih aktif didalam kelas. Namun, upaya penangan tersebut belum seutuhnya dapat mengatasi berbagai masalah yang terjadi, karena hanya dapat mengatasi permasalahan dari segi keaktifan mahasiswa di kelas sedangkan upaya untuk mengatasi bahan ajar berbahasa asing dan kurangnya penjabaran rumus belum terselesaikan.

Hasil analisis lembar observasi awal terhadap 25 mahasiswa yang telah mengontrak matakuliah Gelombang dan Optik dapat dilihat pada tabel 1. Lebih dari 50\% mahasiswa menyatakan bahwa rata-rata materi pembelajaran gelombang pada matakuliah Gelombang dan Optik memiliki tingkat kesulitan pemahaman yang cukup tinggi. Dengan persentase kesulitan tertinggi sebesar64\% pada materi pembelajaran Gelombang Bola dan Tabung, Gelombang Elektromagnetik, Pemantulan Gelombang dan Gelombang Berdiri. Kesulitan-kesulitan yang dirasakan mahasiswa lebih didominasi oleh permasalahan bahan ajar. Bahan ajar yang digunakan oleh dosen dan mahasiswa untuk perkuliahan Gelombang dan Optik adalah "Introduction of Wave Phenomena". Menurut mahasiswa, bahan ajar tesebut yang belum menjelaskan penurunan rumus yang lengkap, masih minim dalam visualisasi konten, penggunaan bahasa asing dan kurangnya penjelasan jawaban dari latihan soal. Permasalahan tersebut mengakibatkan $76 \%$ mahasiswa merasa bahwa bahan ajar yang selama ini digunakan belum maksimal dan 
belum mampu memenuhi kebutuhan mahasiswa untuk membantu mereka dalam mempelajari materi perkuliahan.

Tabel 1.Hasil Pengisian Lembar Observasi

\begin{tabular}{|c|c|c|}
\hline No & Butir Pertanyaan & Persentase Jawaban Mahasiswa \\
\hline 1 & $\begin{array}{l}\text { Apakah Anda sudah mengontrak mata } \\
\text { kuliah Gelombang dan Optik? }\end{array}$ & $\begin{array}{l}\text { - Sudah }(100 \%) \\
\text { - Belum }(0 \%)\end{array}$ \\
\hline 2 & $\begin{array}{l}\text { Materi pembelajaran apa saja yang sulit } \\
\text { untuk dipahami pada mata kuliah } \\
\text { Gelombang dan Optik? (Boleh lebih dari } \\
\text { satu) }\end{array}$ & $\begin{array}{l}\text { - Gelombang Bulat dan Tabung(64\%) } \\
\text { - Osilasi Gelombang(52\%) } \\
\text { - Gerak Gelombang (60\%) } \\
\text { - Gelombang Mekanik(52\%) } \\
\text { - Gelombang Bunyi dalam Zat Padat, Cair, dan } \\
\text { Gas (56\%) } \\
\text { - Pemantulan Gelombang dan Gelombang } \\
\text { Berdiri(64\%) } \\
\text { - Efek Doppler Gelombang Bunyi dan } \\
\text { Gelombang Kejut(60\%) } \\
\text { - Gerak Elektromagnetik (64\%) }\end{array}$ \\
\hline 3 & $\begin{array}{l}\text { Kesulitan seperti apa yang Anda temukan } \\
\text { selama mempelajari mata kuliah } \\
\text { Gelombang dan Optik? (Boleh lebih dari } \\
\text { satu) }\end{array}$ & $\begin{array}{l}\text { - Penurunan rumus }(80 \%) \\
\text { - Penyelesaian latihan soal }(52 \%) \\
\text { - Lainnya: bahasa yang sulit dipahami (80\%) }\end{array}$ \\
\hline 4 & $\begin{array}{l}\text { Apa saja jenis bahan ajar yang digunakan } \\
\text { oleh dosen untuk menjelaskan materi } \\
\text { perkuliahan Gelombang dan Optik? } \\
\text { (Boleh lebih dari satu) }\end{array}$ & $\begin{array}{l}\text { - } \text { Buku }(76 \%) \\
\text { - } \operatorname{Modul}(48 \%) \\
\text { - } \operatorname{LKS}(12 \%) \\
\text { - E-book }(32 \%)\end{array}$ \\
\hline 5 & $\begin{array}{l}\text { Referensi/buku apa yang digunakan dosen } \\
\text { untuk menjelaskan materi perkuliahan } \\
\text { Gelombang dan Optik? }\end{array}$ & $\begin{array}{l}\text { Sebutkan } \\
\text { - Introduction to Wave } \\
\text { (Hirose\&Lonngren) }(100 \%) \\
\text { - Buku sumber internet (28\%) }\end{array}$ \\
\hline 6 & $\begin{array}{l}\text { Apakah referensi dan bahan ajar yang ada } \\
\text { saat ini sudah memenuhi kebutuhan Anda } \\
\text { dalam memahami materi perkuliahan } \\
\text { Gelombang dan Optik? }\end{array}$ & - Sudah $(24 \%)$ \\
\hline 7 & $\begin{array}{l}\text { Apa yang menyebabkan bahan ajar } \\
\text { tersebut masih belum bisa mempermudah } \\
\text { dan memenuhi kebutuhan Anda dalam } \\
\text { memahami materi perkuliahan Gelombang } \\
\text { dan Optik? }\end{array}$ & $\begin{array}{l}\text { Sebutkan } \\
\text { - Bahasa yang cukup sulit dipahami (84\%) } \\
\text { - Penurunan rumus yang kurang lengkap (60\%) } \\
\text { - Ketersediaan visualisasi materi pembelajaran } \\
(52 \%)\end{array}$ \\
\hline 8 & $\begin{array}{l}\text { Apakah penggunaan bahasa pada bahan } \\
\text { ajar (yang digunakan dosen) telah } \\
\text { mempermudah Anda untuk memahami } \\
\text { materi pembelajaran mata kuliah } \\
\text { Gelombang dan Optik? }\end{array}$ & $\begin{array}{l}\text { - } \mathrm{Ya}(12 \%) \\
\text { - } \operatorname{Tidak}(88 \%)\end{array}$ \\
\hline 9 & $\begin{array}{l}\text { Jika ada pengembangan bahan ajar untuk } \\
\text { mata kuliah Gelombang dan Optik, } \\
\text { kriteria bahan ajar seperti apa yang ada } \\
\text { inginkan? }\end{array}$ & $\begin{array}{l}\text { Jelaskan } \\
\text { - Bisa menjabarkan rumus secara rinci }(80 \%) \\
\text { - Bisa mempermudah pemahaman bahasa } \\
\text { ( } 72 \%) \\
\text { - Pembahasan contoh soal }(64 \%) \\
\text { - Media pendukung tambahan }(60 \%)\end{array}$ \\
\hline
\end{tabular}


Tabel 2.Hasil Pengisian Angket Kebutuhan Mahasiswa

\begin{tabular}{|c|c|c|}
\hline No & Butir Pernyataa & Persentase Jawaban Mahasiswa \\
\hline 1 & $\begin{array}{l}\text { Apakah Anda menyukai materi } \\
\text { perkuliahan mata kuliah Gelombang dan } \\
\text { Optik? }\end{array}$ & $\begin{array}{l}\text { - } \operatorname{Ya}(44 \%) \\
\text { - } \operatorname{Tidak}(56 \%)\end{array}$ \\
\hline 2 & $\begin{array}{l}\text { Apakah mata kuliah Gelombang dan Optik } \\
\text { merupakan mata kuliah dengan materi } \\
\text { yang sulit dipahami? }\end{array}$ & $\begin{array}{l}\text { - } \mathrm{Ya}(92 \%) \\
\text { - Tidak }(8 \%)\end{array}$ \\
\hline 3 & $\begin{array}{l}\text { Apakah Anda memiliki bahan ajaruntuk } \\
\text { mata kuliah Gelombang dan Optik? }\end{array}$ & $\begin{array}{l}\text { - } \text { Ya(68\%) } \\
\text { - Tidak }(32 \%)\end{array}$ \\
\hline 4 & $\begin{array}{l}\text { Apakah bahan ajaryang Anda gunakan } \\
\text { sudah cukup bagi Anda untuk memahami } \\
\text { mata kuliah tersebut? }\end{array}$ & $\begin{array}{l}\text { - } \operatorname{Ya}(16 \%) \\
\text { - } \operatorname{Tidak}(84 \%)\end{array}$ \\
\hline 5 & $\begin{array}{l}\text { Apakah Anda membutuhkan bahan } \\
\text { belajartambahan untuk menunjang } \\
\text { pembelajaran pada mata kuliah tersebut? }\end{array}$ & $\begin{array}{l}\text { - } \mathrm{Ya}(100 \%) \\
\text { - } \operatorname{Tidak}(0 \%)\end{array}$ \\
\hline 6 & $\begin{array}{l}\text { Apakah Anda pernah menggunakan modul } \\
\text { dalam mempelajari pada mata kuliah } \\
\text { Gelombang dan Optik? }\end{array}$ & $\begin{array}{l}\text { - Ya }(32 \%) \\
\text { - Tidak }(68 \%)\end{array}$ \\
\hline 7 & $\begin{array}{l}\text { Jika tidak pernah, menurut Anda apakah } \\
\text { modul pembelajaran diperlukan dalam } \\
\text { mata kuliah Gelombang dan Optik? }\end{array}$ & $\begin{array}{l}\text { - } \mathrm{Ya}(92 \%) \\
\text { - } \operatorname{Tidak}(0 \%)\end{array}$ \\
\hline 8 & $\begin{array}{l}\text { Konten tambahan apa yang Anda } \\
\text { harapkan terkandung di dalam modul yang } \\
\text { telah ada? (Boleh lebih dari satu) }\end{array}$ & $\begin{array}{l}\text { - Gambar(28\%) } \\
\text { - Penjabaran rumus yang rinci(40\%) } \\
\text { - Simulasi Pembelajaran Interaktif (40\%) } \\
\text { - Lainnya: latihan soal }(44 \%)\end{array}$ \\
\hline 9 & $\begin{array}{l}\text { Apakah Anda tertarik menggunakan } \\
\text { modul pembelajaran untuk mata kuliah } \\
\text { Gelombang dan Optik? }\end{array}$ & $\begin{array}{l}\text { - Sangat tidak tertarik }(0 \%) \\
\text { - Tidak tertarik(0\%) } \\
\text { - Cukup tertarik }(20 \%) \\
\text { - Tertarik }(40 \%) \\
\text { - Sangat tertarik }(40 \%)\end{array}$ \\
\hline 10 & $\begin{array}{l}\text { Menurut anda, apa saja kriteria materi } \\
\text { pembelajaran yang membutuhkan modul } \\
\text { untuk mempelajarinya? }\end{array}$ & $\begin{array}{l}\text { Sebutkan } \\
\text { - Materi pembelajaran yang sulit dipahami } \\
\text { - } 40 \%) \\
\text { - Materi pembelajaran yang belum punya bahan } \\
\text { ajar }(32 \%) \\
\text { - Dsb }(28 \%)\end{array}$ \\
\hline 11 & $\begin{array}{l}\text { Pada mata kuliah Gelombang dan Optik } \\
\text { terdapat salah satu materi pembelajaran } \\
\text { dengan bentuk penjalaran gelombang yang } \\
\text { berbeda dan unik. Menurut Anda apakah } \\
\text { materi tersebut cocok untuk dibuat modul } \\
\text { pembelajaran? }\end{array}$ & $\begin{array}{l}\text { - } \text { Ya }(100 \%) \\
\text { Alasan (beragam) } \\
\text { - Tidak }(0 \%) \\
\text { Alasan }(-)\end{array}$ \\
\hline 12 & $\begin{array}{l}\text { Apakah dalam proses pembelajaran dosen } \\
\text { mata kuliah Gelombang dan Optik telah } \\
\text { menggunakan model, metode, ataupun } \\
\text { strategi pembelajaran? }\end{array}$ & $\begin{array}{l}\text { - } Y a(76 \%) \\
\text { - } \operatorname{Tidak}(24 \%)\end{array}$ \\
\hline 13 & $\begin{array}{l}\text { Menurut Anda, apakah model, metode, } \\
\text { dan strategi pembelajaran perlu untuk } \\
\text { digunakan dalam proses perkuliahan mata } \\
\text { kuliah Gelombang dan Optik? }\end{array}$ & $\begin{array}{l}\text { - } \text { Ya }(100 \%) \\
\text { Alasan (beragam) } \\
\text { - Tidak (0\%) } \\
\text { Alasan (-) }\end{array}$ \\
\hline
\end{tabular}


Hasil analisis angket kebutuhan mahasiswa terhadap pengembangan bahan ajar menunjukkan bahwa mayoritas mahasiswa menyatakan bahwa bahan ajar yang selama ini mereka gunakan pada matakuliah Gelombang dan Optik belum cukup untuk memenuhi kebutuhan mereka. Seluruh mahasiswa dari sampel subjek penelitian menyatakan bahwa mahasiswa membutuhkan bahan ajar tambahan yang dapat menunjang pembelajaran. Mahasiswa menginginkan bahan ajar yang berbahasa Indonesia, berisikan penjabaran rumus yang lengkap, dilengkapi dengan gambar dan simulasi pembelajaran, serta berisikan tambahan latihan soal. Bahan ajar yang baik hendaknya bersifat self contained dan self instruction, yaitu pembelajaran mandiri. Mahasiswa juga menyatakan bahwa mereka setuju jika dilakukan pengembangan bahan ajar, terlebih untuk materi pembelajaran gelombang dengan bentuk penjalaran gelombang yang unik. Keberadaan model, metode, dan strategi pembelajaran juga diharapkan terkandung pada bahan ajar yang akan dikembangkan.

Hasil penelitian dari analisis kebutuhan mahasiswa terhadap bahan ajar mata kuliah Gelombang dan Optik menunjukkan bahwa mahasiswa memerlukan bahan ajar tambahan untuk memahami materi dan konsep pembelajaran pada matakuliah tersebut. Jadi, dapat disimpulkan bahwa peneliti dapat melakukan solusi penyelesaian masalah dengan cara mengembangkan bahan ajar. Pengembangan bahan ajar yang efektif adalah dengan mengembangkan modul pembelajaran. Banyak bentuk dari modul pembelajaran, salah satunya yaitu modul berbentuk cetakan.Modul cetak merupakaan salah satu bahan ajar yang dapat memberikan dampak positif terhadap perkembangan kemampuan mahasiswa dalam memahami materi perkuliahan yang diberikan, serta dapat meningkatkan sikap ilmiah mahasiswa dalam belajar. Hal ini sesuai dengan penelitian terdahulu, yaitu: penelitian Mukarramah, Hartini dan Salam (2016) yang berjudul: "Pengembangan Modul Fisika pada Pokok Bahasan Listrik Dinamis dengan Menggunakan Model Discovery Learning di SMAN 5 Banjarmasin". Jurnal. Banjarmasin: Program Studi Pendidikan Fisika, FKIP, ULM Banjarmasin. Hasil penelitian menunjukkan bahwa bahan ajar tersebut efektif jika di lihat dari tingkat pencapaian ketuntasan hasil tes belajar siswa terhadap tujuan pembelajaran.
Pencapaian keterampilan proses sains siswa yang di amati saat proses pembelajaran dikategorikan baik. Pencapaian sikap ilmiah siswa yang diamati saat proses pembelajaran dikategorikan baik.

Penelitian terdahulu yang dilakukan oleh Zulherman (2018) dengan judul "Physics Module Design of Wave Subject for Secondary School" show that physics learning module with contextual approach on wave material already has correct components, and it is feasible to be used as a companion module. With validation shows interpretation score of $73 \%$ - 93\%.Alternative solutions to physics learning problems that are difficult to understand shows interpretation score $80 \%$. Dari hasil penelitina tersebut, peneliti berencana untuk mengembangkan modul pembelajaran untuk materi Gelombang Bola dan tabung, karena berdasarkan hasil observasi didapatkan data bahwa mahasiswa tertarik untuk menggunakan modul yang dapat menjelaskan materi pembelajaran yang sulit untuk dipahami. Selain itu, mahasiswa juga tertarik untuk menggunakan modul yang berisikan penjelasan mengenai bentuk penjalaran gelombang yang unik. Beberapa kebutuhan mahasiswa tersebut sesuai dengan karakteristik dari pembelajaran Gelombang Bola dan Tabung.

Berdasarkan data hasil penelitian terhadap kebutuhan mahasiswa akan bahan ajar, di peroleh bahwa mahasiswa mengharapkan bahan ajar yang dapat memberikan visualisasi terhadap konsep dari materi pembelajaran. Untuk memenuhi kebutuhan tersebut, peneliti berencana untuk menambahkan bahan ajar tambahan lain berupa simulasi pembelajaran. Oleh karena modul yang dibuat berbentuk cetakan, maka diperlukan media tambahan sebagai tempat untuk meletakkan simulasi pembelajaran yang berbentuk soft file. Jadi, pengembangan bahan ajar berupa modul cetak akan dilengkapi oleh $\mathrm{CD}$ pembelajaran yang memuat simulasi pembelajaran.

Simulasi pembelajaran yang akan dibuat tentunya berkaitan dengan materi Gelombang Bola dan Tabung. Berdasarkan jurnal yang ditulis oleh Fuada, dkk (2013) aplikasi MATLAB merupakan salah satu aplikasi yang mampu membuat dan menggambarkan bentuk gelombang dengan baik. Jadi, peneliti akan menggunakan aplikasi 
Matlab sebagai aplikasi dasar untuk pembuatan

\section{Simpulan dan Saran}

Simpulan

Berdasarkan data hasil penelitian mengenai analisis kebutuhan mahasiswa, dapat disimpulkan bahwa bahan ajar yang perlu dikembangkan pada matakuliah Gelombang dan Optik tepatnya pada materi Gelombng Bola dan Tabung di Universitas Jambi adalah bahan ajar berupa modul cetak yang dilengkapi dengan simulasi yang dikembangkan dengan menggunakan aplikasi MATLAB.

Saran

Penelitian ini merupakan bagian dari penelitian pengembangan modul fisika gelombang pada materi pekuliahan Gelombang Bola dan Tabung yang ditujukan untuk memenuhi kebutuhan mahasiswa akan bahan ajar di prodi Pendidikan Fisika. Dengan adanya penelitian ini dapat menjadi acuan dalam pengembangan modul pada mata kuliah Gelombang dan Optik.

\section{Daftar Pustaka}

Fuada \& Aquari. (2013). Square Wave Generator Circuit Analysis Using simulasi pembelajaran pada CD pembelajaran. Matlab Approach. International Journal Of Engineering Sciences \& Research Technology. ISSN: 22779655. University of Malang.

Kristanto, Dedi. D. (2011).Pengembangan Modul Fisika RSBI Pokok Bahasan Gerak Pada Siswa SMA Kelas X Semester 1 SMA Negeri 1 Purwareja Klampok. Skripsi, Universitas Negeri Semarang.

Mukarramah, dkk. (2016). Pengembangan Modul Fisika pada Pokok Bahasan Listrik Dinamis dengan Menggunakan Model Discovery Learning di SMAN 5 Banjarmasin.Jurnal Fisika Fluks. Volume 13, Nomor 2, Agustus 2016. ISSN: 1829-796X (print); 25141713(online).

Richards, J.C. (2001). Curriculum Development in Language Teaching. Cambridge University: Amerika Serikat.

Zulherman.(2018). Physics Module Design of Wave Subject for Secondary School.Jurnal Ilmiah Pendidikan MIPA. Volume 8.ISSN: 2088-315X (print); ISSN: 2502-5457 (online).. Universitas Muhammadiyah: Jakarta 